\title{
Susceptibility response of varieties and local populations of lupines to Bruchus rufimanus (Coleoptera: Chrysomelidae)
}

\author{
Ivelina NIKOLOVA
}

Received August 27, 2020; accepted April 18, 2021.

Delo je prispelo 27. avgusta 2020, sprejeto 18. aprila 2021 . Susceptibility response of varieties and local populations of
lupines to Bruchus rufimanus (Coleoptera: Chrysomelidae)

Abstract: This study aimed to evaluate the susceptibility response of varieties and local populations of lupines to Bruchus rufimanus in multi-environment field tests. Seed damaged rate and susceptibility index were assessed in each environment and subjected to a heritability-adjusted genotype and genotype $\mathrm{x}$ environment biplot analysis. It was found that the susceptibility index of damaged seeds was positively related to precipitation amounts and humidity, and inversely to min and max temperatures. The seed damaged rate was positively related to temperatures but negatively to rain and humidity. The local polish population WAT and cultivars Pink Mutant, Solnechnii, and Bezimenii 1 had the lowest seed damaged rate and stable position across environments. Meanwhile, these cultivars showed a low susceptibility index and low variability. The discrepancy between the early phenological development of 'Pink Mutant', 'Solnechnii', and 'Bezimenii 1' and the life cycle of B. rufimanus was one of the reasons for manifested tolerance. Correlations between damaged seed and susceptibility index as well as the mass of 1000 seeds and sensitivity index were strongly positive and negative, respectively. 'WAT', 'Pink Mutant', 'Solnechnii', and 'Bezimenii 1' had a clear advantage in defending itself from B. rufimanus attack, which makes them particularly interesting for breeding purposes.

Key words: Bruchus rufimanus; Lupinus albus; HA-GGE biplot analysis; seed damaged rate; susceptibility index
Občutljivostni odziv sort in lokalnih polucij belega volčjega boba na bobarja (Bruchus rufimanus Bohemann, Coleoptera, Chrysomelidae)

Izvleček: Namen raziskave je bil ovrednoti občutljivostni odziv sort in lokalnih populacij belega volčjega boba na bobarja (Bruchus rufimanus) v poljskih poskusih v več okoljih. Stopnja poškodovanosti semen in občjutljivostni indeks sta bila ocenjena $\mathrm{v}$ vseh preučevanih okoljih in analizirana glede na dednost in vplive okolja. Ugotovljeno je bilo, da sta bila občutljivostni indeks in poškodovanost semen pozitivno povezana s količino padavin in vlažnostjo in negativno $\mathrm{z}$ minimalnimi in maksimalnimi temperaturami. Poškodovanost semen je bila pozitivno povezana $s$ temperaturo in negativno s padavinami in vlažnostjo. Lokalna poljska populacija 'WAT' in sorte Pink Mutant, Solnechnii, in Bezimenii 1 so imele najmanj poškodovanih semen in so dobro uspevale $\mathrm{v}$ vseh preučevanih okoljih. Te sorte so imele tudi najmanše vrednosti občutljivostnega indeksa in majhno raznolikost. Neujemanje med zgodnjimi fenološkimi fazami razvoja sort Pink Mutant, Solnechnii in Bezimenii 1 in razvojnim krogom bobarja je bil eden od vzrokov za izkazano toleranco. Korelacije med poškodovanostjo semen in vrednostjo občutljivostnega indeksa kot tudi med maso 1000 semen in občutljivostnim indeksom so bile v prvem primeru močno pozitivne in $\mathrm{v}$ drugem negativne. Sorte WAT, Pink Mutant, Solnechnii in Bezimenii 1 so imele prednost v lastni obrambi pred napadom bobarja, zaradi česar so posebno zanimive za programe žlahtnjenja.

Ključne besede: Bruchus rufimanus; Lupinus albus; HA-GGE biplot analiza; poškodovanost semena; indeks občutljivosti 


\section{INTRODUCTION}

Broad bean beetle, Bruchus rufimanus Boheman, 1833 (Coleoptera: Chrysomelidae) is a common pest on faba beans (Vicia faba L.) all over Europe and worldwide (Roubinet, 2016). Bean beetle hosts, in addition to $V$. faba, are various genera Vicia, Pisum and Lathyrus (Delobel \& Delobel, 2006; Ward, 2018).

Ramos \& Fernández-Carrillo (2011) first reported that lupin plants were a new host of different species from Bruchus genus (Bruchidius rubiginosus (Desbrochers des Loges, 1869). Harris (1980) established that Callosobruchus chinensis Linnaeus, 1758 was an important lupin seed pest, but in a later study, the author found that $B$. rufimanus is one of the most destructive seed pests in lupine (Hurej \& Twardowski Kozak, 2013).

B. rufimanus is univoltine insect. Adults emerge from overwintering sites and enter host crops to feed on pollen for several weeks, which females must terminate reproductive diapause. After that, females lay eggs on the pod surface. The larvae develop in the seeds and the adults emerge at harvest. Bruchids make a round output hole in seeds and go through it. Broad bean beetle move to sheltered winter sites, or they remain in the seed until the following year doing no further damage during storage.

The development duration, reproduction, damage degree and generation viability were determined largely by temperature in many insect species (Zhou Guo et al., 2010; Kutcherov, 2015; Hasan \& Ansary, 2016). For example, changes in development and damage rate by temperature were reported regarding Acanthoscelides obtectus (Say, 1831) (Stewart et al., 2015). However, climatic conditions have a considerable impact on the attack and pest damage.

Control of B. rufimanus is primarily conducted by use of insecticides against adults before oviposition, at the stage of the mid-flowering and early pod-formation. Pyrethroids are one of the most used insecticides but managing adult pest attacks is difficult due to their mobility, and the lack of persistence of pyrethroids at high temperatures (Mansoor et al., 2015).

European restrictions and environmental concerns have increased the need for alternative measures. Site selection, crop rotation, cultivar and seed selection, sowing date and plant density are potential means to pest control. One of the effective alternative measures to beetle management are the identification of tolerant genotypes, integrate these genotypes in breeding programs, and to identify the genes involved in the tolerance mechanisms. In this regard, Szafirowska (2012) found that cultivars and their phenological development affect the activity of B. rufimanus and the quantity of damage. Southgate
(1979) suggested that the seed size and portion remaining following Bruchinae larval feeding among different cultivars were important traits of germination capacity and damage extent. Roubinet (2016) observed differences in susceptibility between several cultivars of Vicia faba L. to B. rufimanus and the timing of flowering or pod formation turned out to be important factors influencing on the bruchid attack.

The application of alternative cropping strategies, specifically the use of different cultivars, is an efficacious and ecologically friendly approach to plant protection against main insect pests.

This study aimed to evaluate the susceptibility response of varieties and local populations of lupines to Bruchus rufimanus in multi-environment field tests.

\section{MATERIAL AND METHODS}

Field trial was conducted with 23 white lupine cultivars: Astra, Nahrquell, Ascar, BGR 6305, Shienfield Gard, WAT, Kijewskij Mutant, Hetman, Start, Amiga (originating from Poland), Garant (originating from Ukraine), Tel Keram, Bezimenii 1, Bezimenii 2, Pflugs Ultra, Termis Mestnii, Horizont, Solnechnii, Pink Mutant, Manovitskii, Barde, Dega, Desnyanskii (originating from Russia) during the period 2014-2016 at the Institute of Forage Crops (Pleven, Bulgaria). Sowing was made by hand, in optimum sowing time, according to the technology of cultivation. The experiment was laid out using a randomized block design. The studied genotypes were grown in an density of 50 plants $\mathrm{m}^{-2}$. Plot units were twenty-three and each plot unit $(5,50 \mathrm{~m}$ broad $\times 2 \mathrm{~m}$ length) in three replications included twelve rows spaced $50 \mathrm{~cm}$ apart.

The soil type is leached chernozem with $\mathrm{pH}_{(\mathrm{KCl})}$ of 5.49 and content of total $\mathrm{N}$ was $34.30 \mathrm{mg} / 1000 \mathrm{~g}$ soil, $\mathrm{P}_{2} \mathrm{O}_{5}$ was $3.72 \mathrm{mg} / 100 \mathrm{~g}$ soil and $\mathrm{K}_{2} 0$ was $37.50 \mathrm{mg} / 100$ $\mathrm{g}$ soil. The study was conducted without irrigation and introduced into the soil nitrogen-phosphorus fertilizers in the following amounts: nitrogen - 30, phosphorus - 60 $\mathrm{kg}$ active substance per 1 ha.

The period from germination to early flowering was determined for quantitative assessment, we used the coefficient of early-ripeness (Kuzmova, 2002) (1):

$\mathrm{Cr}=1+[\{\mathrm{Nc}-\mathrm{Nmin}\} /\{\mathrm{Nmax}-\mathrm{Nmin}\}]$

where: $N c$ is the duration of the period sowing beginning of flowering for the particular cultivar; Nmax and Nmin are the maximum and minimum duration (in days) of the period sowing-beginning of flowering for all tested cultivars.

The values of the coefficient were as followed: for ultra-early ripening cultivars - from 1.00 to 1.17; for 
early-ripening cultivars - 1.17 to 1.33 ; for medium-early ripening cultivars -1.34 to 1.66 and for late-ripening ones $>1.66$.

No chemical control of insect pests was conducted during the growing season. The degree of Bruchus rufimanus damaged seeds was determined after lupin harvesting. Bulk samples containing 1500 seeds were taken for each accession, and seed damaged rate (DR) was calculated by the following formula (2):

$\% D R=$ Number of seeds damaged $x$ 100/ Total number of seeds

Susceptibility index (SI, \%) was calculated by the following formula (3):

$S I=(a-b) / a \times 100$, where

$a$ : mass of 1000 healthy seeds;

$b$ : mass of 1000 seeds damaged by the broad bean beetle

To eliminate interactions between variables and to include genotype and genotype $\mathrm{x}$ environment (GGE) interactions, a HA-GGE biplot analysis was carried out (Yan \& Holland, 2010). Biplot graphs are suitable for simultaneous visualization of interacting factors and based mathematically on SVD (singular-value decomposition) models. They are used frequently, in a comparison of multiple genotypes in different environments (Rubiales et al., 2014; Sánchez-Martín et al., 2014). In this way, the best genotype will have the lowest values for the evaluated trait and stability through all the environments, and low $\mathrm{G} \times \mathrm{E}$ interactions.

To evaluate the influence of environmental factors on DR and SI, different climate variables were subjected to a Non-Metric Multidimensional Scaling (NMDS) ordination (Anderson, 2001). Data on the meteorological variables: rainfall, average air temperature, as well as average relative humidity were obtained from Pleven meteorological station for each environment. In order to focus on the occurrence of bruchids in the field, the climatic parameters used in the analysis ranged from March to June. To determine the relative impact of the selected climatic variables on the performance of DR and SI, canonical correspondence analysis (CCA) was carried out. The analysis was performed using the Paleontological Statistics Software Package (PAST) (Hammer et al., 2001). Relationships between damaged seeds and certain plant traits were tested using multiple regression analysis. The statistical processing of experimental data was conducted using the Statgraphics Plus software program.

A wide range of values for DR and SI were noted for the 23 lupin cultivars studied in the three environments. ANOVA (Table 1) revealed a significant effect of geno- type $(\mathrm{G})$, environment $(\mathrm{E})$ and $\mathrm{G} \times \mathrm{E}$ in both variables, being the highest mean of a square for E, followed by $G$ and the lowest for $\mathrm{G} \times \mathrm{E}$.

\section{RESULTS AND DISCUSSION}

The meteorological conditions during the studied period were different (Figure 1) and had an impact on Bruchus rufimanus development, reproduction and damage rate. April, May and June months in 2015 were characterized by a higher average daily temperature (by 1.0 and $0.7{ }^{\circ} \mathrm{C}$ comparatively to 2014 and 2016) as well as a lower rainfall and air humidity (by 107.1 and 25,5 mm, and 9.7 and 6..7 \% humidity in comparison with 2014 and 2016). Those conditions led to an earlier appearance of bean beetle and their stronger attack compared to other years. The plants were in the sensitive stage of flowering and pod formation to bruchid infestation in May and the first ten days of June. At the same time, the plants suffered from a lack of moisture. During 2016, after sowing, the subsequent dry weather delayed seed germination. In April-June the higher temperatures accelerated the plant development and favored the broad bean beetle attack. The meteorological conditions during 2014 characterized by the highest amount of rainfall and relative humidity combined with low temperatures during the growing season. That suppressed infestation and damage rate of B. rufimanus.

A canonical correlation analysis helped to visualize the distinct relations of DR and SI components to climate variables (Figure 2). Whereas SI was positively related to bulk precipitation and humidity and inversely to Tmin and Tmax, the seed damaged rate was positively related to Tmin and Tmax but negatively to rain and humidity. Moreover, Tmin and Tmax were associated with the environmental 2 droughts (2015) and opposed to rain and humidity during the environmental 1 wet period (2014). Because of a negative effect of rainfall on DR, the seed damage decreasing at rainy seasons, while in driest environments - increasing. This might be due to the fact that rainfall might disturb bruchid oviposition and reduce egg viability (Roubinet, 2016). The opposite, rainfall and humidity had a positive effect, with SI increasing at higher values.

The HA-GGE biplot is the preferred GGE biplot for test environment and genotype evaluation (Yan \& Holland, 2010). The GGE biplot presents the mean characteristic and stability, which gives us an essential visualization of the data (Yan, 2001; Yan \& Rajcan, 2002). A GGE biplot is a biplot based on environment-centered data (Gabriel, 1971), which removes the environment's main effect and integrates the genotypic main effect with the 
Table 1: Analysis of variance for Bruchus rufimanus seed damage rate (DR) and susceptibility index (SI) of the 23 lupin genotypes

\begin{tabular}{lccccc}
\hline \multicolumn{1}{c}{ Source } & Df & Sum Sq & Mean Sq & F value & $\operatorname{Pr}(>\mathrm{F})$ \\
\hline ENV & 2 & 17878.48 & $8939.239^{*}$ & 3213.711 & $8.11 \mathrm{E}-10$ \\
REP(ENV) & 6 & 16.690 & 2.782 & 58.494 & $8.03 \mathrm{E}-35$ \\
GEN & 22 & 14129.08 & $642.231^{\star}$ & 11.232 & $1.2 \mathrm{E}-11$ \\
ENV ${ }^{\star}$ GEN & 44 & 2515.781 & $57.177 *$ & 1202.361 & $9.9 \mathrm{E}-153$ \\
PC1 & 23 & 2511.448 & 109.193 & 2296.210 & \\
PC2 & 21 & 4.333 & 0.206 & 4.340 & \\
Residuals & 132 & 6.277 & 0.048 & & \\
\hline & & & SI & & \\
\hline ENV & 2 & 2755.412 & $1377.706^{*}$ & 381.713 & $4.74 \mathrm{E}-07$ \\
REP(ENV) & 6 & 21.656 & 3.609 & 33.620 & $2.21 \mathrm{E}-24$ \\
GEN & 22 & 4587.940 & $208.543^{*}$ & 11.733 & $5.64 \mathrm{E}-12$ \\
ENV ${ }^{\star}$ GEN & 44 & 782.079 & $17.775^{\star}$ & 165.566 & $1.74 \mathrm{E}-96$ \\
PC1 & 23 & 678.050 & 29.480 & 274.600 & - \\
PC2 & 21 & 104.029 & 4.954 & 46.140 & - \\
Residuals & 132 & 14.171 & 0.107 & - & - \\
\hline
\end{tabular}

Legend: DF- degrees of freedom Sum Sq - sum of the squared Mean Sq - mean square ENV - environments

REP(ENV) - replicates within each environment GEN - genotype $\mathrm{ENV}^{*} \mathrm{GEN}-$ term of genotype ${ }^{*}$ environment interaction) PC1 and PC2 - Principal component

* Significant at 0,0001 level probability

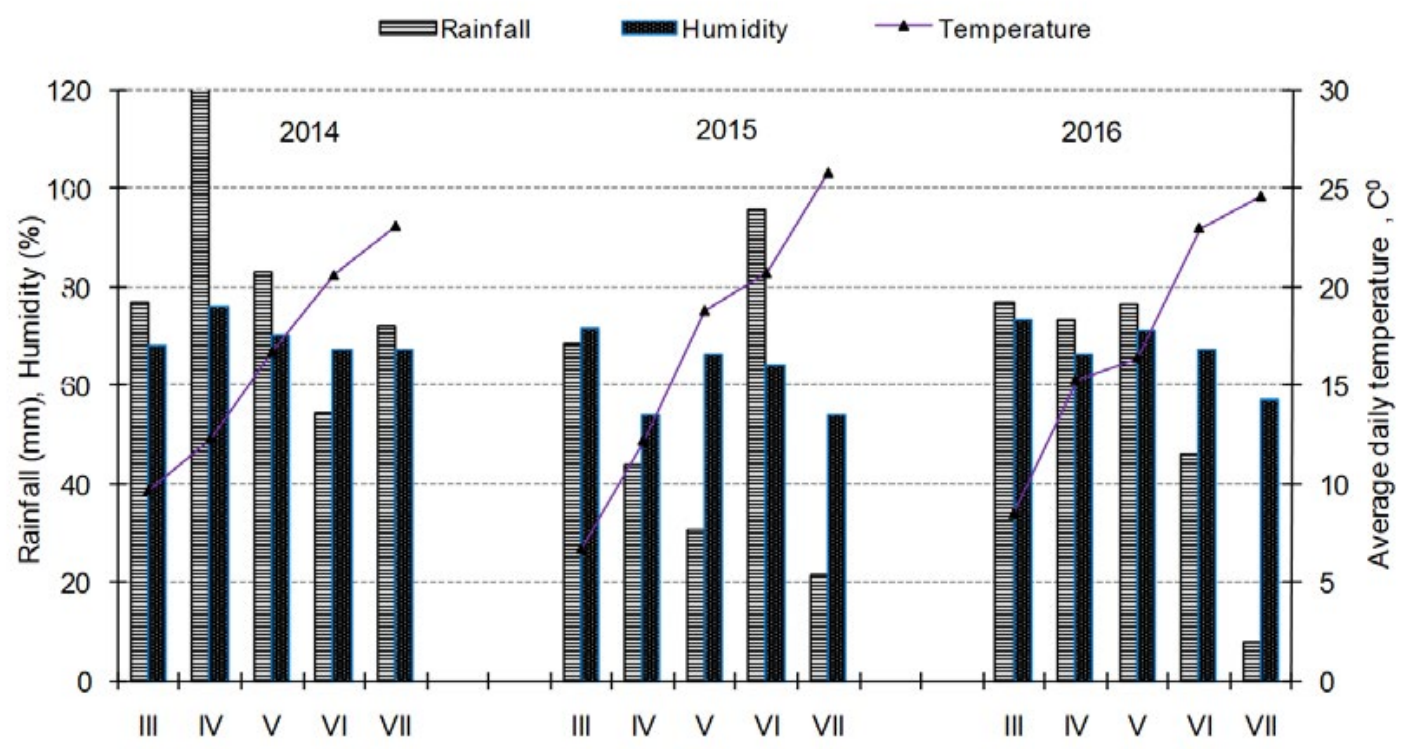

Fig. 1: Meteorological characteristic of the period 2014-2016 


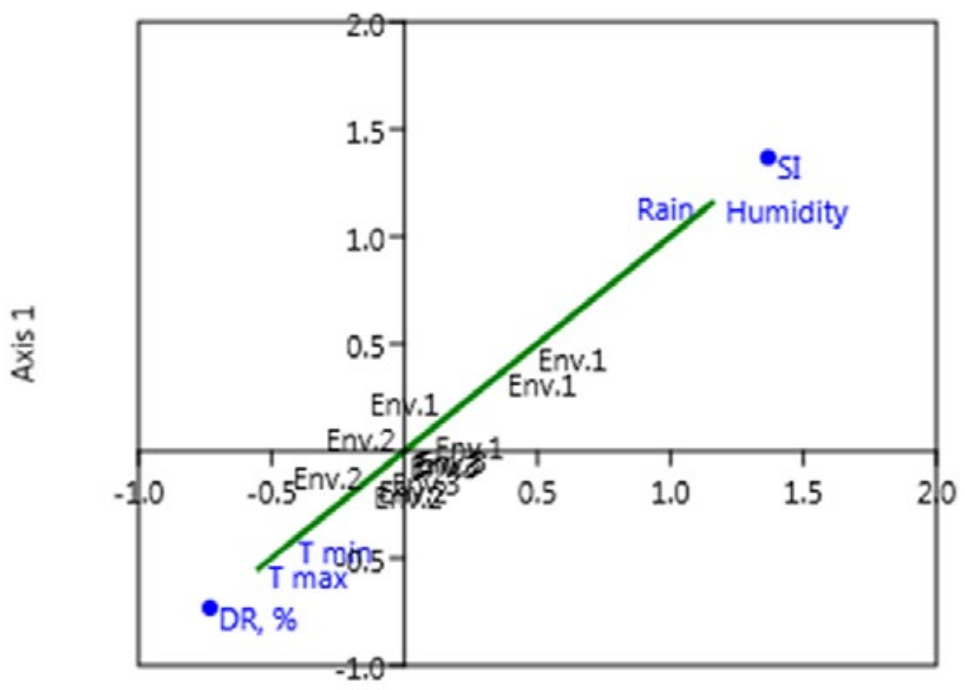

Axis 1

Fig. 2: CCA graph based on the correlation of DR and I of Bruchus rufimanus for 23 lupin cultivars according to several climatic parameters. The period analyzed was from April to June, Tmax $=$ maximum temperature; Tmin $=$ minimum temperature; $\mathrm{DR}=$ Seed damaged rate (\%); SI, \% = Susceptibility index

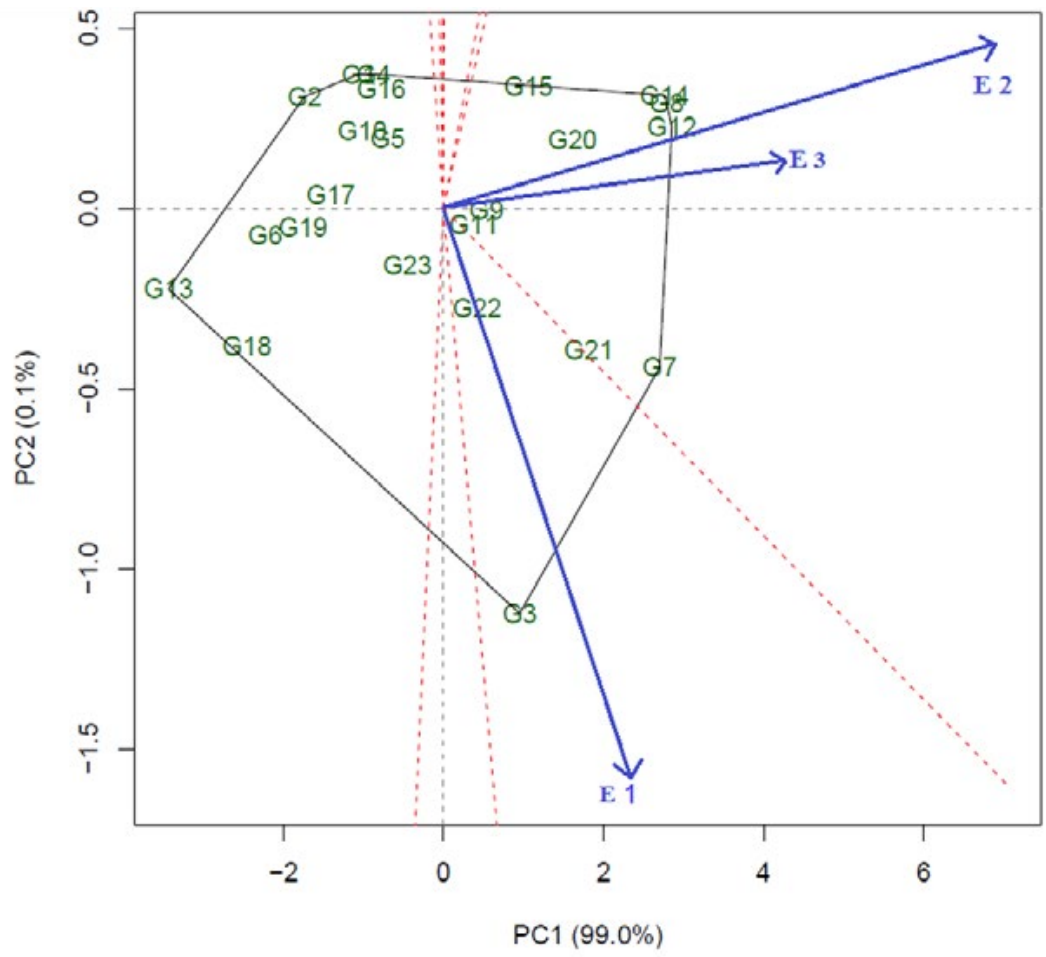

Fig. 3: The GGE biplot based on seed damaged rate (2014-2016). The genotypes are designated with the symbol "G" and the respective number from 1 to 23, as follow G1-Astra, G2-Nahrquell, G3-Ascar, G4-BGR 6305, G5-Shienfield Gard, G6-WAT, G7Kijewskij Mutant, G8-Hetman, G9-Start, G10-Amiga, G11-Garant, G12-Tel Keram, G13-Bezimenii 1, G14-Bezimenii 2, G15Pflugs Ultra, G16- Termis Mestnii, G17-Horizont, G18-Solnechnii, G19-Pink Mutant, G20-Manovitskii, G21-Barde, G22-Dega, G23-Desnyanskii. The years are designated with the letter E and number 1; 2; and 3 for 2014, 2015 and 2016, respectively, Note: G14 and G8 are heavily overlapped, as well as G1 and G4; G5 and G10 
genotype-by-environment interaction effect of a genotype-by-environment dataset (Yanunt et al., 2000).

According to the results of GGE biplot analysis (Fig. 3 ), the difference in vector length among environments showed phenotypic variances within the environments. Based on the discrimination power (vector length) E1, followed by E2 were most discriminating, GGE biplot manifested clearly long vectors for E1 и Е2 and shorter vector for $\mathrm{E} 3$.

Although there are no strict relations, the goodness of approximation for the correlation coefficients by the angles is related to the goodness of fit of the biplot. Depending on the angle between two environment vector correlation is different. In that aspect, the environments were more or less positively correlated (acute angles). An exception was found between E1 and E2 environments which were not correlated (a right angle). In addition, within the environmental group, E 1 was apparently less associated with E3, while strongly positively correlated were E2 and E3.

In order to determine which of the 23 lupin genotypes studied were the least affected by bean beetle attack based on their representation in the biplots, the ranking of the genotypes (considering stability across the environments studied) for both variables assessed is shown in Table 2.

Thus, in the case of damaged seeds, the genotype with the lowest DR was G13 (6.3\%) despite exhibiting environmental interactions, followed by the genotypes G18 (10.9 \%), G6 (11.8\%), G19 (14.0 \%) and G17 $(15.5 \%)$, whose responses were more stable, as indicted by their location close to the axis 1 . The results showed that genotypes G19, G17 and G6 were considered as the most stable being the ones closest to the midpoint of the boxplot and less preferred by B. rufimanus. Relatively stable and damage tolerant with little difference in each other, exhibited G1, G4 and G16, Genotype G2 had lower values for that trait but was more affected by the environment. The most susceptible genotypes (high DR, represented on the opposite side of the biplot) were G12 (35.8 \%), G8 (34.7\%) and G14 (34.6\%).

The two principal components determined $99.1 \%$ of the dispersion.

The GGE biplot based on SI (Fig. 4), analysis represented $96.2 \% \%$ of the total trait variation between two principal components. The environment with the shortest vector was E1, and the longest - E2. The most discriminative environment was $\mathrm{E} 2$ in which less rainfall was registered. Genotype 6 was the most responsive to that trait (the lowest value of SI, $5.6 \%$ ), and it was followed by G19, G18, G13 (7.4; 7.9 and $9.0 \%$, respectively) (see Table 2). A similar level of sensitivity showed G2 and G1 too, According to the ordinate, G6 was highly stable, followed by G19 within the group of the low susceptibility index. Lower variability had G18 and G13, G4 had a mean susceptibility index to the grand mean.

Table 2: Ranking of the twenty-three lupin genotypes with the lowest levels of Bruchus rufimanus seed damaged rate (DR) and susceptibility index (SI) (ascending order)

\begin{tabular}{cccccccccccc}
\hline & \multicolumn{3}{c}{ DR } & & & & \multicolumn{5}{c}{ SI } \\
\hline 1 & G13 & 11 & G5 & 21 & G14 & 1 & G6 & 11 & G23 & 21 & G7 \\
2 & G18 & 12 & G23 & 22 & G8 & 2 & G19 & 12 & G3 & 22 & G12 \\
3 & G6 & 13 & G11 & 23 & G12 & 3 & G18 & 13 & G22 & 23 & G14 \\
4 & G2 & 14 & G22 & & & 4 & G13 & 14 & G11 & & \\
5 & G19 & 15 & G9 & & 5 & G2 & 15 & G9 & \\
6 & G17 & 16 & G3 & & 6 & G1 & 16 & G5 & \\
7 & G1 & 17 & G15 & & 7 & G17 & 17 & G20 & \\
8 & G10 & 18 & G20 & & & 8 & G10 & 18 & G21 & \\
9 & G4 & 19 & G21 & & 9 & G4 & 19 & G8 & \\
10 & G16 & 20 & G7 & & 10 & G16 & 20 & G15 & \\
\hline
\end{tabular}

Stability throughout the environments has been taken into account by considering each genotype position in the biplots 


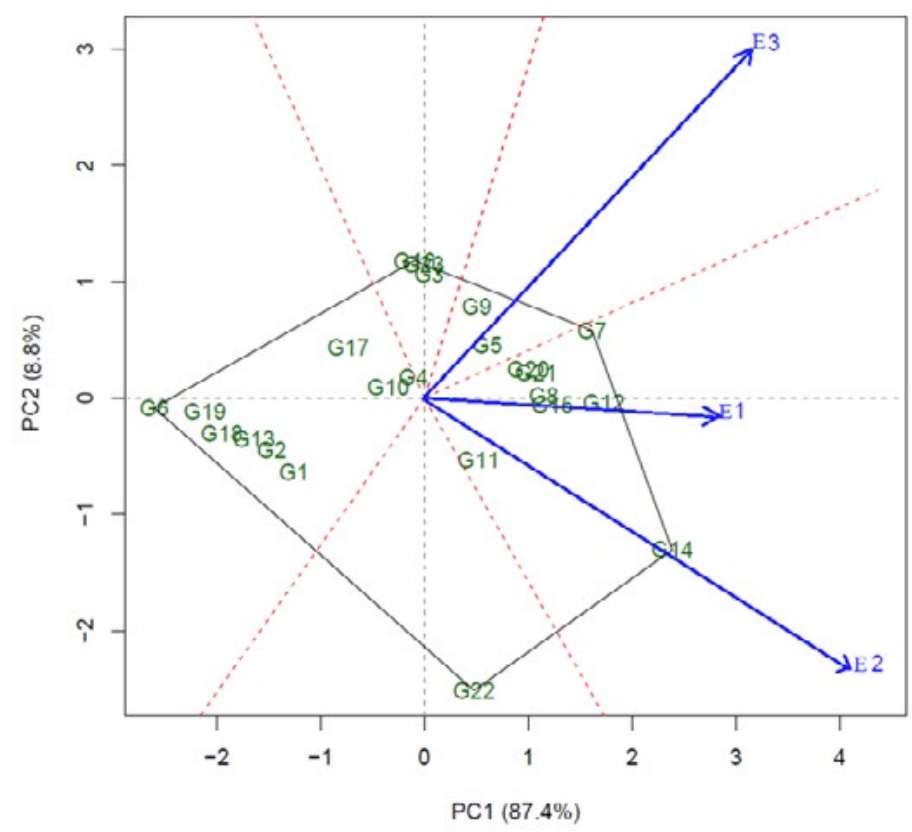

Fig. 4: The GGE biplot based on susceptibility index (2014-2016). The genotypes are designated with the symbol "G" and the respective number from 1 to 23, as follow G1-Astra, G2-Nahrquell, G3-Ascar, G4-BGR 6305, G5-Shienfield Gard, G6-WAT, G7Kijewskij Mutant, G8-Hetman, G9-Start, G10-Amiga, G11-Garant, G12-Tel Keram, G13-Bezimenii 1, G14-Bezimenii 2, G15Pflugs Ultra, G16- Termis Mestnii, G17-Horizont, G18-Solnechnii, G19-Pink Mutant, G20-Manovitskii, G21-Barde, G22-Dega, G23-Desnyanskii. The years are designated with the letter E and number 1; 2; and 3 for 2014, 2015 and 2016, respectively, Note: G23, G16 and G3 are heavily overlapped, as well as G21 and G20

The genotype presenting the highest value in that trait and identified like strong sensitive was G14, followed by F12 and G7. Furthermore, the genotype G14 was considerable variable (poor stability) together with G22. Also, G14 had the highest value in E2, which was the most favourable for its susceptibility.

Pearson correlations between DR and SI with genotype as a weighting variable $(r=+0.812, p=0.0001)$ revealed a significantly high coefficient value, which suggests a strong association between both parameters.

The reduced DR and SI for G6, G19, G18 and G13 might be the result of the combination of different resistance mechanisms. The antixenosis mechanisms might be involved in the resistance of these genotypes by reducing the oviposition over their pods as the result of morphological, phenological or (and) chemical plant factors that adversely affect the insect behaviour. Such morphological traits hindering the penetration of the larvae could be related to a pod or seed coat thickness, seed mass, chemical compounds that hamper the penetration of pods or seeds (alkaloids in lupins) (Keneni et al., 2011). The discrepancy between the phenological development of the host plant and the life cycle of bean beetle could be a marker for tolerance too. In our case, several differences among the phenological development of the genotypes, affecting B. rufimanus damage, were observed (Fig. 5). After passing of the budding stage were found differences in the growing period length. Varieties Astra, Termis Mestnii and Barde were characterized with the lowest average duration of the period germination-beginning of flowering (37 days). 'Pink Mutant' (G19), 'Solnechnii' (G18), and 'Bezimenii 1' (G13) had a lower average duration of the period (38 days) and occupied an intermediate position. In the remaining stages of the growing season, the trend remained. The early cultivars (with early flowering) reached technical maturity on average after about 129134 days and the late ones - for 140-148 days. Cultivars Ascar (G3), Termis Mestnii (G16), Barde (G21), as well as Pink Mutant (G19), Solnechnii (G18), and Bezimenii 1 (G13), could be included in the group of ultra-early ripening cultivars (the coefficient of early-ripeness of 1.00-1.14). Medium-early ripening cultivars were Astra (G1), Kijewskij Mutant (G7), Start (G9), BGR 6305 (G4), WAT (G6), Garant (G11), Tel Keram (G12), Bezimenii 2 (G14), Pflugs Ultra (G15) (coefficient of early-ripeness > 1.34) and the late-ripening one's - Hetman (G8), Shienfield Gard (G5) and Nahrquell (G2) (coefficient > 1.66).

Several cultivars of the ultra-early ripening group 
stood out with considerably lower values of damage traits (DR and SI). For example, cultivars Pink Mutant, Solnechnii, and Bezimenii 1 had early flowering and slightly preference by bean beetle, while late-ripening 'Hetman' and 'Shienfield Gard' was considerably prefered by bruchids. The discrepancy between the early phenological development of those cultivars and the life cycle of $B . r u$ fimanus was one of the reasons for manifested tolerance.

There was published evidence of the influence of cultivar on damage caused to Vicia faba grain by B. rufimanus (Ebedah et al., 2006; Szafirowska, 2012). In those studies was suggested that plant architecture, flowering period and abundance, and the timing of pod formation were the key factors that influence the activity of $B$. rufimanus. According to Bruce et al. (2011), Ceballos et al. (2015), several plant characteristics could adversely affect insect behaviour. Authors found that some susceptible genotypes flowered later than the average, which could have contributed in some way to the escape of these pea plants from bruchid infestation. More recent research identified phenological tolerance in cultivars with an early flowering stage becoming unavailable to the weevils during the period when the attack is likely to be most severe (Bell \& Crane, 2016).

On the other hand, results showed the mass of 1000 seeds strongly negatively correlated with the sensitivity index, $r=-0.842$. It was noticed that genotypes exceeding 300 g per 1000 seeds, such as G6 (322.2 g), G19 (317.1 g), G13 (308.2 g), and G18 (304.3 g) were distinguished by low susceptibility indexes (from 5.6 to $7.9 \%$ ). In contrast, genotypes with much smaller seeds like G14, G21, and G20 (173.2, 222.2, and 232.9, respectively) were characterized by higher SI values (from 19 to $23 \%$ ). Larger seeds are considerably richer in nutrients than small seeds, where larvae destroyed a large amount of them. For example, Mateus et al. (2011) reported that the attack by bruchids caused a significant reduction in seed mass, between 0.03 (large seeds) and $0.08 \mathrm{~g}$ (smaller seeds), depending on the genotypes/cultivars, corresponding to a decrease in nutrients available to the embryo development. In that aspect, the genotype 14, G21 and G20 were one of the cultivars with the highest susceptibility indexes as the larva destroyed most of the grain content for its feeding.

Also, antixenosis mechanisms might be involved in the tolerance of these genotypes by reducing the preference of bean beetle adults for feeding as the result of chemical plant factors that adversely affect insect behaviour. Probably, studied lupin cultivars may differ chemically to a great extent (in alkaloid content), and in that context, some species of them may even be toxic to some animals. The negative role of different alkaloids in cultivated lupins was indicated by Ströcker et al. (2013). The presence of such antinutrient substances in the genotypehost probably explain the preferences of bruchids.

About effect of some botanical oils, including lupin seeds on the granary weevil, Sitophilus granarius reported Makarem et al. (2017). According to authors, lupine oil protected the grain against weevils up to the 6th-week post-treatment achieving mortalities between 60.0 and $100 \%$. Meanwhile, the highest degree of inhibited oviposition and adult emergence was detected with a lupine oil treatment compared with other oils.

On the other hand, proteinase inhibitors are potential candidates for biocontrol of insect pests since insect digestive proteinases are promising targets towards control of various insects (Sharma et al., 2012). Proteases have been found to be effective against many Coleopteran (Elden, 2000). Scarafoni et al. (2008) reported for the inhibitory properties of a trypsin inhibitor from Lupinus albus $\mathrm{L}$, a leguminous plant believed to be devoid of any protease inhibitor. Several protease inhibitors have been reported to exhibit inhibitory activity against insect proteases. Although the proteases were not evaluated in the present study, seed genotypes slightly affected by broad bean beetle had presumably protease inhibitors suppressing strongly its activity.

It is necessary to examine not only the individual effect of plant traits but also their mutual impact on the beetle damage. The applied regression analysis (ANOVA) in Table 3 showed that the interaction of plant traits had a significant effect on the damaged seed rate. The susceptibility index had the highest regression coefficient ( $\mathrm{r}$ $=1.915$ ) (Table 3, below). It had a significant positive effect. The coefficient of early-ripeness had a significantly strong effect on the B. rufimanus choice $(\mathrm{r}=-1.687)$ but correlated negatively. The mass of 1000 seeds had a low positive effect $(r=0.048)$ on the damaged seeds in the complex interaction between plant traits and seed damage rate.

According to the results above, G6, G19, G18 and G13 seems to have a clear advantage in defending itself from B. rufimanus attack. The low DR and SI make genotypes particularly interesting for breeding purposes because it probably presents a combination of different mechanisms like seed mass and phenological development adversely affect $B$. rufimanus behaviour. The possibility of combining these two types of resistance mechanisms have great importance because of the durability of the tolerance and successfully overcome an attack if one of these levels is broken. 


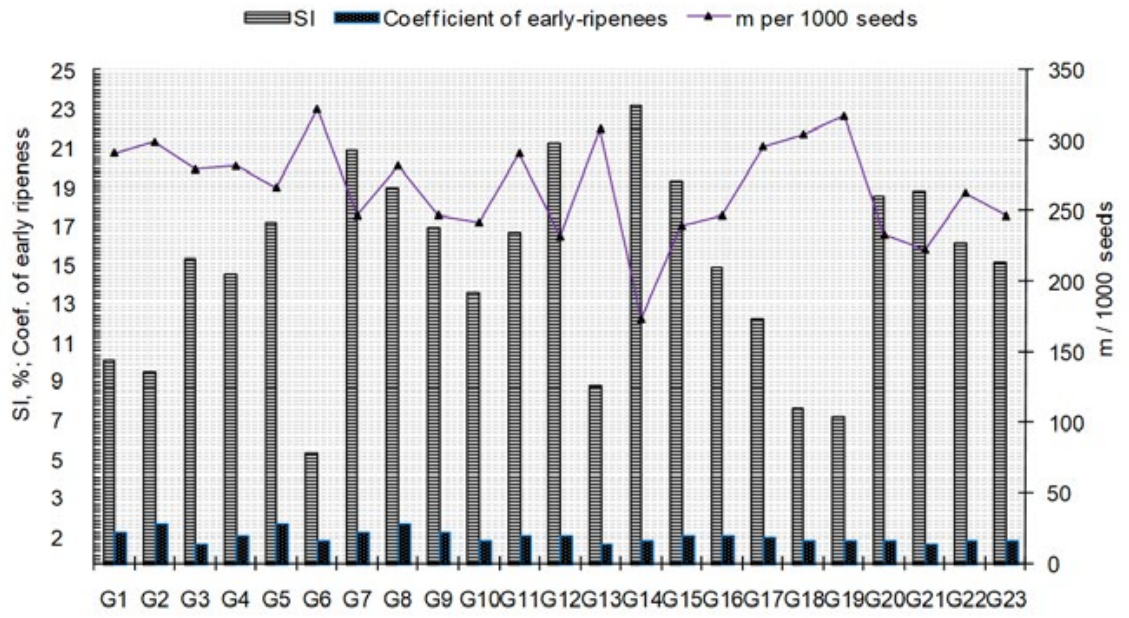

Legend: SI- susceptibility index; G1-Astra, G2-Nahrquell, G3-Ascar, G4-BGR 6305, G5-Shienfield Gard, G6-WAT, G7-Kijewskij Mutant, G8Hetman, G9-Start, G10-Amiga, G11Garant, G12-Tel Keram, G13-Bezimenii 1, G14-Bezimenii 2, G15-Pflugs Ultra, G16- Termis Mestnii, G17-Horizont, G18-Solnechnii, G19-Pink Mutant, G20-Manovitskii, G21-Barde, G22Dega, G23-Desnyanskii.

Fig. 5: Characteristics of lupin genotypes

Table 3: Regression coefficient of the damaged seed rate depending on some plant parameters for lupin genotypes

\begin{tabular}{|c|c|c|c|c|c|c|}
\hline Source & $d f$ & SS & $M S$ & & $F$ & Significance F \\
\hline Regression & 3 & 1319.330 & 439.780 & & 33.140 & 0.051 \\
\hline Residual & 19 & 252.143 & 12.270 & & & \\
\hline Total & 22 & 1571.470 & & & & \\
\hline Parameter & Coefficients & Standard Error & t Stat & $\mathrm{P}$-value & Lower $95 \%$ & Upper $95 \%$ \\
\hline Intercept & -17.145 & 15.206 & -1.127 & 0.000 & -48.970 & 14.681 \\
\hline SI & 1.915 & 0.339 & 5.653 & 0.000 & 1.206 & 2.623 \\
\hline$M$ of seeds & 0.048 & 0.045 & 1.059 & 0.087 & -0.047 & 0.142 \\
\hline CER & -1.687 & 2.843 & -0.593 & 0.100 & -7.639 & 4.264 \\
\hline
\end{tabular}

Legend: SI- Susceptibility index, M of seeds- m per 1000 seeds, CER- Coefficient of early-ripeness

\section{CONCLUSIONS}

Bruchus rufimanus damage was affected by climate parameters. The susceptibility index of damaged seeds was positively related to precipitation amounts and humidity, and inversely to min and max temperatures. The seed damaged rate was positively related to temperatures but negatively to rain and humidity.

The local polish population WAT and cultivars Pink Mutant, Solnechnii, and Bezimenii 1 (G6, G19, G18 and G13, respectively) had the lowest seed damaged rate and stable position across environments. Meanwhile, these cultivars showed a low susceptibility index and low variability.

The discrepancy between the early phenological development of 'Pink Mutant', 'Solnechnii', and 'Bezimenii 1 ' and the life cycle of B. rufimanus was one of the reasons for manifested tolerance. Correlations between damaged seed and susceptibility index as well as the mass of 1000 seeds were strongly positive and negative, respectively.

Cultivars Pink Mutant, Solnechnii, Bezimenii 1 and local population WAT had a clear advantage in defending itself from $B$. rufimanus attack, which makes them particularly interesting for breeding purposes.

The matching of an early flowering with higher seed mass in cultivars could be used as markers for tolerance against broad bread weevil, and like an effective method for plant defence.

\section{ACKNOWLEDGEMENTS}

This work would not have been possible without the kind support of the technical staff who have been supportive during the field experiments. 


\section{REFERENCES}

Anderson, M.J. (2001). A new method for non-parametric multivariate analysis of variance. Austral Ecology, 26, 3246. https://doi.org/10.1111/j.1442-9993.2001.01070.pp.x

Bell, S., \& Crane, E. (2016). Farming oilseed rape without neonicotinoids. Research Report Commissioned by Friends of the Earth. Retrieved from https://cdn.friendsoftheearth. uk/sites/default/files/downloads/Farming\%20Oilseed\%20 Rape\%20without\%20Neonicotinoids.pdf

Bruce, T.J., Martin, J.L., Smart, L.E., \& Pickett, J.A. (2011). Development of semiochemical attractants for monitoring bean seed beetle, Bruchus rufimanus. Pest Management Science, 67, 1303-1308. https://doi.org/10.1002/ps.2186

Ceballos, R., Fernbndez, N., Zyciga, S., \& Zapata, N. (2015). Electrophysiological and behavioral responses of pea weevil Bruchus pisorum L. (Coleoptera: Bruchidae) to volatiles collected from its host Pisum sativum L. Chilean Journal of Agricultural Research, 75, 202-209. https://doi.org/10.4067/ S0718-58392015000200009

Delobel, B., \& Delobel, A. (2006). Dietary specialisation in European species groups of seed beetles (Coleoptera: Bruchidae: Bruchinae). Oecologia, 149, 428-443. https:// doi.org/10.1007/s00442-006-0461-9

Ebedah, I.M.A., Mahmoud, Y.A., \& Moawad, S.S. (2006). Susceptibility of some faba bean cultivars to field infestations with some insect pests. Research Journal of Agricultural and Biological Science, 2, 537-540.

Elden, T.C. (2000). Effects of proteinase inhibitors and plant lectins on the adult alfalfa beetle (Coleoptera: Curculinoidae). Journal of Entomological Science, 35, 62-69. https://doi.org/10.18474/0749-8004-35.1.62

Gabriel, K.R. (1971). The biplot graphic display of matrices with application to principal component analysis. Biometrika, 58, 453-467. https://doi.org/10.2307/2334381

Hammer, Ø., Harper, D.A.T., \& Ryanh, P.D. (2001). PAST: paleontological statistics software package for education and data analysis. Palaeontologia Electronica, 4, 1-9. https:// palaeo-electronica.org/2001_1/past/past.pdf

Harris, B.M. (1980). Insects associated with the lupin (Lupinus angustifolius) cultivars fest and uniharvest. Ph.D. thesis, University of Canterbury, Lincoln College, New Zealand, pp. 248

Hasan, F., \& Ansari, S. (2016). Temperature-dependent development and demography of Zygogramma bicolorata (Coleoptera: Chrysomelidae) on Parthenium hysterophorus. Annals of Applied Biology, 168, 81-92. https://doi. org/10.1111/aab.12244

Hurej, M., Twardowski, J.P., \& Kozak, M. (2013). Weevil (Coleoptera: Curculionidae) assemblages in the fields of narrow-leafed lupin sown as pure stand and intercropped with spring triticale. Zemdirbyste-Agriculture, 100(4), 393-400. https://doi.org/10.13080/z-a.2013.100.050

Keneni, G., Bekele, E., Getu, E., Imtiaz, M., Damte, T., Mulatu, B., \& Dagne, K. (2011). Breeding Food Legumes for Resistance to Storage Insect Pests: Potential and Limitations. Sustainability, 3(9), 1399-1415. https://doi. org/10.3390/su3091399

Kutcherov, D. (2015). Temperature dependent development in
Chrysomela vigintipunctata (Coleoptera: Chrysomelidae), a stenothermal early-season breeder. Journal of Thermal Biology, 53, 9-14. https://doi.org/10.1016/j. jtherbio.2015.08.001

Kuzmova, K. (2002). World agro-climatic analogues of Bulgaria on the conditions of cultivation of peas. Jubilee session „120 years of agricultural science in Sadovo", 113-118.

Makarem, H.A.E., Kholy, S.E.E., Abdel-Latif, A., \& Seif, A.I. (2017). Effect of some botanical oils on the granary weevil, Sitophilus granarius (L.) (Coleoptera: Curculionidae). Egyptian Journal of Experimental Biology (Zoology), 13(2), 273-282.https://doi.org/10.5455/egysebz.20171025013938

Mansoor, M.M., Afzal, M., Raza, A.B.M., Akram, Z., Waqar, A., \& Afzal, M.B.S. (2015). Post-exposure temperature influence on the toxicity of conventional and new chemistry insecticides to green lacewing Chrysoperla carnea (Stephens) (Neuroptera: Chrysopidae). Saudi Journal of Biological Sciences, 22, 317-321. https://doi.org/10.1016/j. sjbs.2014.10.008

Mateus, C., Mexia, A., Duarte, I., Pereira, G., \& Tavares de Sousa, M. (2011). Evaluation of damage caused by bruchids (Coleoptera: Bruchidae) on peas (Pisum sativum L.). Acta Horticulturae, 917, 125-132. https://doi.org/10.17660/ ActaHortic.2011.917.15

Ramos, R.Y., \& Fernández-Carrillo, E. (2011). Life cycle and behaviour of the lupine seed beetle, Bruchidius rubiginosus (Desbrochers, 1869) in the Iberian Peninsula (Coleoptera: Bruchidae). Boletín de la Sociedad Entomológica Aragonesa, 31 (12), 253-259. Retrieved from: http://sea-entomologia. org/Publicaciones/PDF/BOLN_49/253259BSEA49Bruchid iusrubiginosusciclo.pdf

Roubinet, E. (2016). Management of the broad bean weevil (Bruchus rufimanus Boh.) in faba bean (Vicia faba L.). Department of Ecology, Swedish University of Agricultural Sciences (SLU). Technical report. Retrieved from https:// pub.epsilon.slu.se/13631/1/roubinet_e_160704.pdf

Rubiales, D., Flores, F., Emeran, A.A., Kharrat, M., Amri, M., Rojas-Molina, M.M., \& Sillero, J.C. (2014). Identification and multi-environment validation of resistance against broomrapes (Orobanche crenata and Orobanche foetida) in faba bean (Vicia faba). Field Crops Research, 166, 58-65. https://doi.org/10.1016/j.fcr.2014.06.010

Sánchez-Martín, J., Rubiales, D., Flores, F., Emeran, A.A., Shtaya, M.J.Y., Sillero, J.C., Allagui, M.B., \& Prats, E. (2014). Adaptation of oat (Avena sativa) cultivars to autumn sowings in Mediterranean environments. Field Crops Research, 156, 111-122. https://doi.org/10.1016/j. fcr.2013.10.018

Scarafoni, A., Consonni, A., Galbusera, V., Negri, A., Tedeschi, G., Rasmussen, P., Magni, C., \& Duranti, M. (2008). Identificaion and characterization of a Bowman-Birk inhibitor active towards trypsin but not chymotrypsin in Lupinus albus seeds. Phytochemistry, 69, 1820-1825. https://doi.org/10.1016/j.phytochem.2008.03.023

Sharma, P., Nath, A.K., Kumari, R., \& Bhardwaj, S.V. (2012). Purification, characterization and evaluation of insecticidal activity of trypsin inhibitor from Albizia lebbeck seeds. Journal of Forestry Research, 23(1), 131-137. https://doi. org/10.1007/s11676-012-0243-7 
Shazali, M.E.H. (1989). The susceptibility of faba bean and other seed legumes to infestation by Bruchidius incarnatus $(\mathrm{BOH}$, and Callosobruchus maculatus (F,) (Coleoptera: Bruchidae). AGRIS since: 1989. Retrieved from http://agris,fao,org/ agris-search/search,do?recordID=QV8900071

Southgate, B.J. (1979). Biology of the Bruchidae. Annual Review of Entomology. 24. 449-473. https://doi.org/10.1146/annurev.en.24.010179.002313

Stewart AJA, Bantock TM, Beckmann BC, Botham MS, Hubble D, \& Roy DB. (2015). The role of ecological interactions in determining species ranges and range changes. Biological Journal of the Linnean Society, 115, 647-663. https://doi. org/10.1111/bij.12543

Ströcker, K., Wendt, S., Kirchner, W.H., \& Struck, Ch. (2013). Feeding preference of the weevils Sitona gressorius and Sitona griseus on different lupin genotypes and the role of alkaloids. Arthropod-Plant Interact, 7, 579-589. https://doi. org/10.1007/s11829-013-9273-0

Szafirowska, A. (2012). The role of cultivars and sowing date in control of broad bean weevil (Bruchus rufimanus Boh.) in organic cultivation. Vegetable Crops Research Bulletin, 77, 29-36. DOI: https://doi.org/10.2478/v10032-012-0013-2

Ward, R.L. (2018). The biology and ecology of Bruchus rufimanus (bean seed beetle). Ph.D. tesses, Newcastle University England.

Yan, W., \& Holland, J.B. (2010). A heritability-adjusted GGE biplot for test environment evaluation. Euphytica, 171, 355-369. https://doi.org/10.1007/s10681-009-0030-5

Yan, W., Hunt, L.A., Sheng, Q., \& Szlavnics, Z. (2000). Cultivar evaluation and mega-environment investigation based on GGE biplot. Crop Science, 40, 597-605. https://doi. org/10.2135/cropsci2000.403597x

Yan, W. (2001). GGEbiplot-a Windows application for graphical analysis of multi-environment trial data and other types of two-way data. Agronomy Journal, 93, 11111118. https://doi.org/10.2134/agronj2001.9351111x

Yan, W., \& Rajcan, I. (2002). Biplot analysis of test sites and trait relations of soybean in Ontario. Crop Science, 42, 1, 11-20. https://doi.org/10.2135/cropsci2002.0011

Zhou, Z., Guo, J., Chen, H., \& Wan, F. (2010). Effects of temperature on survival, development, longevity, and fecundity of Ophraella communa (Coleoptera: Chrysomelidae), a potential biological control agent against Ambrosia artemisiifolia (Asterales: Asteraceae). Environmental Entomology, 39, 1021-1027. https://doi. org/10.1603/EN09176 